\title{
MAKNA INJIL BERDASARKAN ROMA 1: 16-17 DAN IMPLEMENTASINYA BAGI GEREJA MASA KINI
}

\author{
Kejar Hidup Laia \\ Sekolah Tinggi Teologi Anugerah Misi Nias Barat \\ gohilaia89@gmail.com
}

Abstract: $\quad$ The fall of the first man (Adam) into sin caused man to lose the glory of God, man died and was separated from God. The gospel is glad tidings of Jesus Christ who died, rose again to save everyone who believes. To believe the gospel means to believe in the redemptive work of Christ, to reject the gospel is to reject salvation. In the Gospel God's truth is revealed to everyone who believes in Him. This truth is related to the absolute truth of God that no one has. The truth of God revealed in the Gospels is related to the truth that God has done through the death and resurrection of the Lord Jesus to save sinners. Salvation can only be received through faith. Faith is a gift from God given to humans so that they believe in Jesus Christ as Lord and Savior. The gospel gives hope and sets people free from death. To get salvation everyone must listen to the gospel. The task of evangelism is the responsibility of the Church (believers) to preach the message of salvation in the power of the Holy Spirit to sinners so that they repent and have faith in Jesus and become disciples who obey the Great Commission of the Lord Jesus.

Keywords: $\quad$ The meaning of Gospel, the power of God, its implementation, Today's Church.

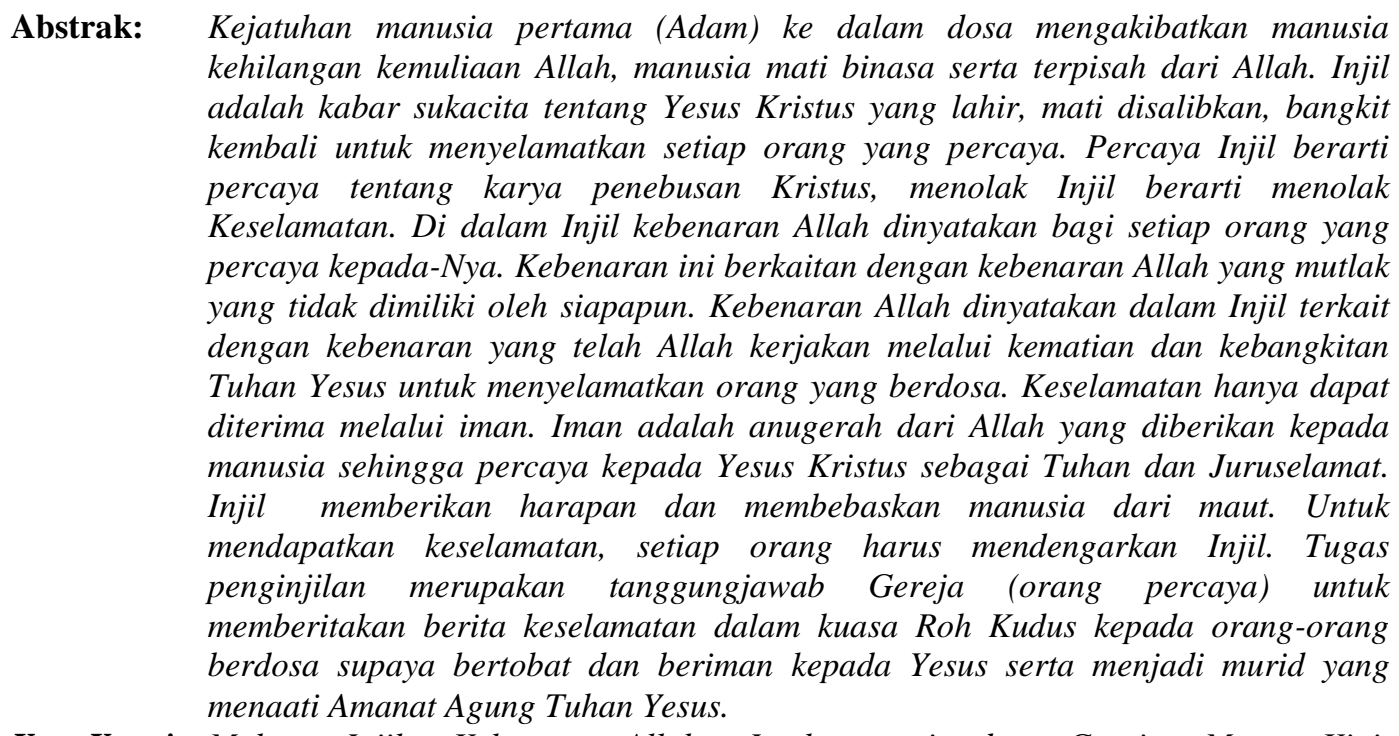

Kata Kunci: Makna Injil, Kekuatan Allah, Implementasi dan Gereja Masa Kini. 


\section{PENDAHULUAN}

Alkitab menceritakan pada waktu Allah menciptakan langit, bumi beserta manusia sungguh amat baik. Akan tetapi dosa mengakibatkan segala sesuatu yang tadinya baik menjadi buruk. Oleh karena kejatuhan manusia ke dalam dosa (Kej. 2 dan 3) manusia membutuhkan secara mutlak keselamatan dari dosa, maka Allah memberikan janji penyelamatan dengan tujuan yang terpenting yaitu untuk membebaskan manusia dari maut (Kej. 3:15; Mat. 1:21; Gal. 4:4; I Tim. 2:5). Allah senantiasa mengasihi manusia dan memberikan kesempatan untuk bertobat dari segala dosanya. Seperti yang dijelaskan Alkitab bahwa karena begitu besar kasih Allah akan dunia ini, sehingga Ia telah mengaruniakan Anak-Nya yang tunggal, supaya setiap orang yang percaya kepada-Nya tidak binasa, melainkan beroleh hidup yang kekal (Yoh. 3:16). Janji Allah tergenapi di dalam Injil. Injil adalah kabar sukacita tentang Yesus Kristus yang telah mati dan bangkit kembali untuk menyelamatkan setiap orang yang percaya. Percaya Injil berarti percaya tentang karya penebusan Kristus, menolak Injil berarti menolak keselamatan. Kabar Injil adalah kebutuhan kekal setiap orang karena di dalam Injil kebenaran Allah dinyatakan bagi setiap orang yang percaya kepada-Nya. Kebenaran ini berkaitan dengan kebenaran Allah yang mutlak yang tidak dimiliki oleh siapapun. Kebenaran Allah dinyatakan dalam Injil terkait dengan kebenaran yang telah Allah kerjakan melalui kematian dan kebangkitan Tuhan Yesus untuk menyelamatkan orang yang berdosa. Iman adalah anugerah dari Allah yang diberikan kepada manusia sehingga percaya kepada Yesus Kristus sebagai Tuhan dan juruselamat. Iman dalam bahasa aslinya $\pi \imath \sigma \tau \imath \sigma \sigma \alpha \mu \alpha$ dengan percaya. Dibenarkan karena percaya Kristus mati, dikuburkan, dibangkitkan dan naik ke 
Surga Karena itu perkerjaan iman dibenarkan Allah dan pemberian Allah. Iman timbul dari pendengaran karena pemberitaan Injil dan dikerjakan oleh Roh Kudus dalam diri manusia. Sehingga orang percaya mengalami kelahiran kembali dan menjadi manusia baru.

Gereja (orang percaya) dipanggil untuk memberitakan Injil. ${ }^{1}$ Istilah Gereja dalam bahasa Yunani $\varepsilon \kappa \kappa \lambda \varepsilon \sigma \iota \alpha$ perkataan Yesus terhadap Petrus di Kaisarea Filipi, Aku akan mendirikan jemaat-Ku, Matius 16:18 Gereja atau $\varepsilon \kappa \kappa \lambda \varepsilon \sigma \iota \alpha \sigma \tau \iota \kappa o \sigma$ berarti kumpulan orang percaya kepada Yesus, qahal (dalam bahasa Ibrani) berarti perkumpulan, $\varepsilon \kappa \kappa \alpha \lambda \varepsilon 0$ (kata kerja) berarti dipanggil keluar. ${ }^{2}$ Maksudnya dan tujuan dalam penelitian ini adalah bagaimana gereja masa kini mengimplementasikan tentang Injil adalah Kekuatan Allah yang menyelamatkan setiap orang percaya. Karena panggilan untuk memberitakan Injil adalah suatu tugas yang mulia yang diberikan oleh Tuhan Yesus kepada setiap orang percaya (Lih. Matius 28:18-20). Amanat Agung Tuhan Yesus yang harus dilaksanakan oleh murid-murid-Nya, yaitu setiap orang percaya pergi memberitakan Injil dan memuridkan.

\section{METODE PENELITIAN}

Peneliti mengunakan metode kualitatif. Dengan pendekatan eksposisi Kitab Roma 1: 16-17 serta menggunakan studi kepustakaan (Library Research) untuk mendapatkan informasi yang akurat tentang penelitian. ${ }^{3}$ Penulis menggunakan

\footnotetext{
${ }^{1}$ Kejar Hidup Laia, "Sikap Hamba Tuhan terhadap Jemaat yang Mudur dari Pelayanan," Illuminate: Jurnal Teologi dan Pendidikan Kristiani 3, no. 1 (2020): 40-60.

2 Saur Hasugian, "Karaktersik Garam Dunia," Jurnal Pascasarjana STBI 8, no. 1 (2011): 104-105.

${ }^{3}$ Andreas B. Subagyo, Pengantar Riset Kuantitatif dan Kualitatif (Bandung: Yayasan Kalam Hidup, 2014), 125. 
buku-buku pokok yang dibutuhkan dalam eksegese dan eskpsosisi. Penulis juga menerapkan metode hermeneutika dalam melakukan penafsiran terhadap ayatayat yang akan dibahas. Penulis akan memberikan penjelasan secara deskriptif tentang eksposisi Roma 1: 16-17 dan memberikan penjelasan tentang latar belakang masalah. Pada bagian pembahasan penulis akan melakukan kajian untuk menjawab problematika yang muncul pada latar belakang. Hasil dari pembahasan tersebut akan dirangkum pada bagian kesimpulan. Penulis menggunakan referensi manajemen untuk menolong dalam membuat referensi dan daftar pustaka.

\section{HASIL}

Tujuan penginjilan adalah untuk menghasilkan murid. Tuhan Yesus memberikan amanat kepada para murid sebelum Dia terangkat ke Surga, sebagaimana tertulis dalam Injil Matius 28: 18-20. Tuhan Yesus ingin supaya semua suku bangsa mendengarkan Injil, dan percaya, beriman serta menjadi murid yang sejati. Kata murid adalah orang yang mau belajar. Tetapi arti murid tidak hanya cukup belajar saja, melainkan murid bisa memuridkan dan mengajar apa yang dipelajarinya kepada orang lain.

Dari penjelasan di atas tentang tujuan penginjilan yakni menghasilkan murid. Pada kenyataanya beberapa gereja hanya menekankan pada fungsi persekutuan, ibadah dan pelayanan saja sedang penginjilan tidak ada dalam program gereja. ${ }^{4}$ Gereja hanya berfokus pada pembangunan fisik dan mengabaikan tugas gereja yang sesungguhnya. Sehingga implementasi pemberitaan Injil sebagai kekuatan Allah yang menyelamatkan tidak dilaksanakan oleh gereja. 


\section{PEMBAHASAN}

Injil adalah kekuatan Allah yang menyelamatkan berdasarkan Roma 1: 1617. Teks ini berbicara tentang Injil sebagai kekuatan Allah yang di dalamnya

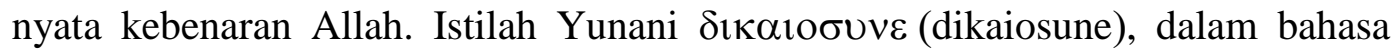
Latin Iustitia, sebagai 'keadilan' Allah yang mengganjar manusia sesuai

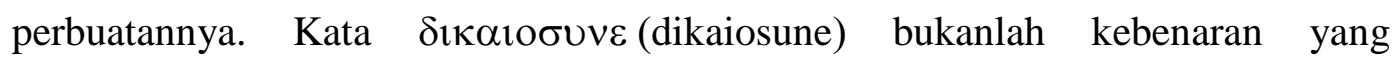
mengganjar (keadilan), melainkan kebenaran yang membenarkan. ${ }^{5}$ Manusia dibenarkan, ini adalah status yang dikaruniakan oleh Allah.

Arland J. Hultgren menjelaskan Paulus tidak berbicara semata-mata tentang kebenaran yang terkait dengan orang-orang yang percaya. Paulus berbicara tentang kebenaran yang dinyatakan di dalam Injil tentang Anak Allah, terkait dengan pesan yang dinyatakan Allah tentang keselamatan yang dikerjakan oleh Allah kepada manusia. ${ }^{6}$ John Calvin menjelaskan Injil adalah kekuatan Allah yang menyelamatkan, tetapi manusia tidak dapat selamat kalau berita itu tidak berasal dari Injil, Allah menyatakan kebenaran-Nya sendiri yang membebaskan manusia dari neraka. ${ }^{7}$ Jadi kebenaran adalah dasar keselamatan manusia dan itu hanya dinyatakan dalam Injil.

Rasul Paulus menulis surat kepada Jemaat di Roma yang sama sekali belum dikenal dan belum pernah dikunjunginya dengan tujuan supaya jemaat di Roma dapat meresponi pemberitaan Injil yang disampaikan oleh Paulus dengan

\footnotetext{
${ }^{5}$ Van den End, Tafsiran Surat Roma (Jakarta: BPK Gunung Mulia, 1995), 55.

${ }^{6}$ Arland J. Hultgren, Paul's Gospel and Mission (Philadelphia: Fortress Press, 1973), 31.

${ }^{7}$ John Calvin, Commentaries Epistle Of Paul The Apostle The Romans (Michigan: Eerdmans
} Publishing, 1947), 63. 
konsep yang benar. ${ }^{8}$ Paulus memberikan penjelasan lebih lanjut bahwa Injil itu adalah kekuatan Allah yang menyelamatkan dan di dalamnya nyata kebenaran Allah.

Vincent menuliskan Injil bukanlah sekedar kekuatan yang ada dalam diri Allah, tetapi Injil itu sendiri pribadi yang penuh dengan energi atau kekuatan. Injil adalah berita yang baik untuk menyelamatkan setiap orang percaya yang digerakkan oleh Roh Kudus dan berita itu berdasarkan belas kasihan dan anugerah Roh Kudus yang bekerja dan berkuasa dalam hati orang berdosa yang terpilih untuk diselamatkan. ${ }^{9}$ Pemberitaan Injil merupakan tugas orang percaya sepenuhnya. Orang percaya wajib memberitakan Injil kepada setiap orang yang belum percaya ${ }^{10}$ Injil tidak mengandung kebodohan seperti yang dipikirkan oleh dunia, hal yang senada dikatakan oleh Jack Cottrell bahwa tidak perlu takut untuk memberitakan Injil karena Injil tidak mengandung kebodohan dan kelemahan seperti yang dipikirkan dunia. ${ }^{11}$ Injil adalah alat untuk menyatakan kemahatahuan, kemahakuasaan kekuatan Allah untuk menyelamatkan orang yang berdosa.

Orang Yahudi memiliki konsep bahwa Injil sama sekali berbeda dengan yang dipahami oleh Paulus. ${ }^{12}$ Orang Yahudi memiliki konsep tersendiri terhadap keselamatan yaitu persembahan korban dan melakukan Hukum Taurat. Sehingga keselamatan bagi mereka dilandaskan atas perbuatan. ${ }^{13}$ Bagi orang Yahudi Injil bukanlah satu-satunya jalan untuk dapat selamat, melalui perbuatan dan ketaatan terhadap Taurat dan sunat maka seseorang dapat diselamatkan sehingga orang

8 Geoffrey B. Wilson, Romans (Edinburgh: Great Britain, 1977).

${ }^{9}$ Kenneth S. Wuest, Wuest's Word Studies from the Greek New Testament (Michigan: Eerdmans Publishing, 1974), 10.

10 Kejar Hidup Laia, "Prinsip Kedatangan Yesus Ke Dua Kali," Nias Barat: STTAM, 2019, IV.

11 Jack Cottrell, Romans Volume 1 (Joplin: College Press, 1998), 1.

12. End, Tafsiran Surat Roma, 6.

13 Lukas Tjandra, Latar Belakang Perjanjian Baru II (Malang: Gandum Mas, 1994), 99. 
Yahudi seringkali menolak Injil bahkan menolak Yesus Kristus sebagai Tuhan dan Juruselamat.

Berdasarkan Roma 1:16-17 pusat pemberitaan Paulus adalah Injil kepada orang Yahudi maupun bukan Yahudi. Surat Roma ini tidaklah mudah diterima oleh orang Yahudi. Orang Yahudi meyakini dan mempersoalkan tentang kedudukan sebagai umat pilihan Tuhan dan posisi ini tidak ada yang menggantikannya. Paulus mendefenisikan Injil (Yun.

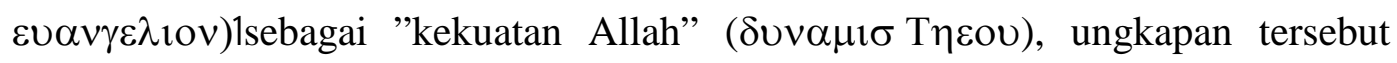
menunjuk kepada ciri kristologi paulus. Dalam Roma 1: 16-17 Paulus mengutip Habakuk 2: 4 dan 3: 19 serta mengombinasikannya dengan Mazmur 140: 8. Paulus menegaskan bahwa "Injil adalah kekuatan Allah yang menyelamatkan."14 Paulus memberikan penegasan ini untuk mempertajam pemahaman bahwa Injil bukanlah sekadar informasi tentang penyelamatan Allah. Injil adalah representasi dari kuasa Allah yang menyelamatkan. ${ }^{15}$ Tindakan penyelamatan terjadi di dalam Injil dan tujuannya adalah untuk menyelamatkan baik orang Yahudi maupun non Yahudi.

\section{Eksposisi Roma 1:16-17}

Roma 1: 16-17 adalah satu perikop yang memiliki satu kesatuan makna. Kedua ayat ini merupakan tema dari seluruh Surat Roma. Tema surat Roma dipusatkan dalam perikop ini, yang menyatakan bahwa di dalam Tuhan Yesus dinyatakan kebenaran Allah sebagai jawaban terhadap murka-Nya kepada manusia berdosa. Roma 1: 16 sebelum partisipel memiliki dua fungsi sebagai kata

\footnotetext{
14 Samuel Benyamin Hakh, Perjanjian Baru: Sejarah, Pengantar dan Pokok-pokok Teologisnya (Bandung: Bina Media Informasi, 2010), 203-204.

${ }^{15}$ Kejar Hidup Laia, "Memahami Tugas Utama Hamba Tuhan Berdasarkan Surat II Timotius 4:1-5 Dan Aplikasinya Pada Masa Kini," Jurnal Teologi Berita Hidup 2, no. 2 (31 Maret 2020): 110-27, https://doi.org/10.38189/jtbh.v2i2.35.
} 
sifat dan sebagai pembuat fungsi. Kehadiran artikel mengindikasikan sebagai substantive atau sebagai kata sifat berfungsi untuk partisip. Tentu saja partisipel dapat menjadi substantival atau kata kata sifat tanpa artikel, meskipun ada

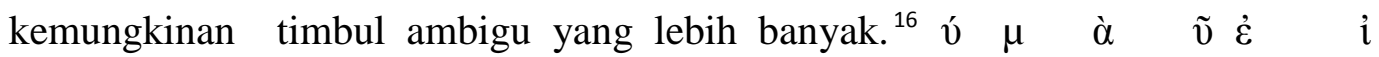

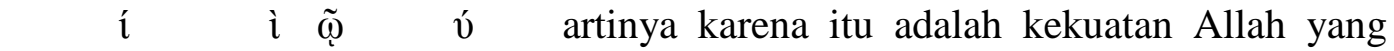
menyelamatkan setiap yang percaya. Kalimat ini merupakan artikel yang mendahului partisipel sehingga artikel disini memiliki dua fungsi sebagai substantival dan pembuat fungsi untuk partisipel. Namun, yang lebih tepat untuk fungsi artikel dalam bagian ini lebih tepat berfungsi sebagai pembuat fungsi bagi

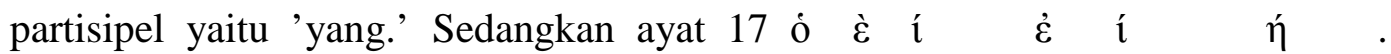
dalam bahasa Inggris artinya but the righteous shall live by faith. Kata sifat sering

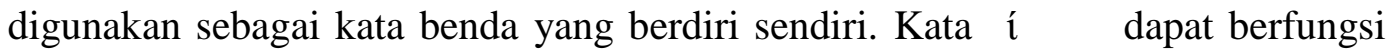
sebagai substantive.

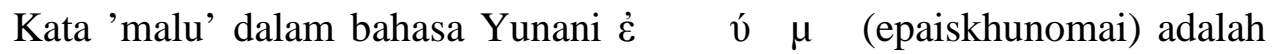
kata kerja indikatif, present middle, orang pertama tunggal atau passive deponent yang memiliki arti 'malu.' Dalam hubungan dengan Kristus atau Injil, kata malu adalah lawan mengaku, menganut dan memberi kesaksian. Kata 'malu' sama artinya dengan menyangkal, tidak mengakui dan tidak memberitakan. Manusia memiliki sifat malu terhadap orang lain (Lih. 2Timotius 1: 8; 16), namun sufat malu itu tidak merupakan unsur yang utama. Dalam teks Roma 1: 16 menunjukkan bahwa Paulus tidak malu memberitakan Injil. Kata 'malu' untuk menyatakan bahwa Injil harus di beritakan kepada siapa pun juga. ${ }^{17}$ Jadi 1996), 241.

${ }^{16}$ Daniel B. Wallace, Greek Grammar Beyond the Basics (Michigan: Zondervan Publishing House,

17 Verlag Kohlhammer G. Stuttart, Exegetical Dictionary Of the New Testament (Michigan: Eerdmans Publishing Company Grand Rapids, 1991), 42. 
kata 'malu' merujuk kepada sikap terhadap Injil. Paulus tidak takut mengambil resiko untuk memberitakan Injil di Roma apapun yang harus dialami, Paulus tidak takut dan malu karena memberitakan Injil kepada siapa saja merupakan kerinduannya. Paulus berani mengakui Yesus adalah Tuhan melalui pemberitaan Injil. Banyak orang Kristen sering kali malu atau takut memberitakan Injil karena alasan takut ditolak, dikucilkan bahkan dibunuh, maka untuk menghindari hal-hal tersebut banyak orang Kristen memilih untuk cukup berbuat baik. Ronald Q Leaveel dalam bukunya Evangelism: Christ Imperative Commission, menuliskan bahwa "para anggota gereja 95\% tak pernah memenangkan jiwa bagi Tuhan artinya tidak menginjili karena belum lahir baru." ${ }^{18}$ Hal tersebut menunjukkan yang melakukan penginjilan hanya 5\%. Rasul Paulus menegaskan bahwa memberitakan Injil adalah suatu keharusan bukan pilihan bagi orang percaya (Lih. I Korintus 9: 16).

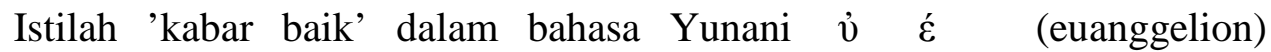

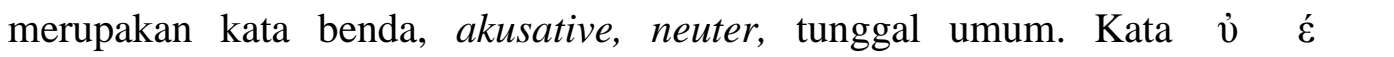
(euanggelion) dalam konteks dunia klasik mengacu kepada pahala yang diberikan

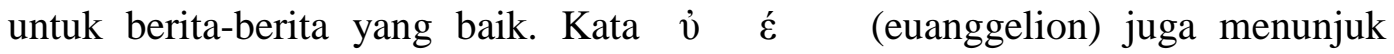
kepada apa yang dikabarkan, kemenangan, kemudian berita kesukaan lain. Injil adalah kabar baik bahwa Allah di dalam Yesus Kristus telah memenuhi janjijanji-Nya kepada Israel, dan bahwa suatu jalan keselamatan telah dibuka bagi semua orang. Injil dalam Perjanjian Lama tidaklah bertentangan, tetapi pemenuhan dari Allah. Dalam bagian ini Injil sebagai kekuatan Allah bukan sekedar menyatakan ide-ide, tetapi sebagai perwakilan dari Allah untuk

${ }^{18}$ Harold L. Fickett JR, Kepercayaan Kaum Baptis, Suatu Pedoman (Semarang: Lembaga Literatur Baptis, 1985), 92. 
menyatakan tentang kuasa Allah untuk menebus dosa manusia. Injil untuk menyatakan bagaimana cara Allah menyatakan pernyataan dari kuasa-Nya.

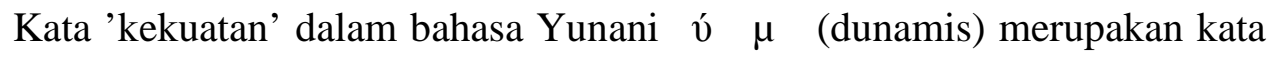
benda nominative, feminism, tunggal umum. Dalam Perjanjian Lama kekuatan Allah dan nama-Nya dapat di pakai secara bersamaan atau memiliki arti yang sama, seringkali menggantikan atau pun mewakili nama Allah. Kata 'kekuatan' merupakan kata lain yang di senangi Paulus. Kata ini dalam Perjanjian Baru digunakan 48 kali, sedangkan dalam surat Roma kata ini dipakai 8 kali. Pikiran mengenai daya kekuatan ini muncul berulang kali dalam tulisan-tulisannya (I Tes.1:5; IKor. 1: 18-25; 2: 1-5). Injil merupakan kekuatan Allah dan tidak ada kuasa lain di dunia ini yang dapat menyelamatkan diri dari murka Allah.

Pandangan umum pengertian Injil adalah kabar baik yang berisi tentang keselamatan setiap orang yang percaya. Injil dihadirkan bukan hanya dengan kekuatan (ITes. 1: 5), tapi Injil itu sendiri adalah tentang Allah. Injil menyatakan kebenaran Allah dan memimpin kepada keselamatan semua orang yang percaya. ${ }^{19}$ Kekuatan yang di maksud dalam bagian ini adalah kekuatan yang mengubahkan sifat yang paling mendasar dan paling dalam dari manusia, memperbaharui spiritual dan memperbaiki moral seseorang dengan totalitas, itu adalah kekuatan dari Injil yang memberikan harapan dan membebaskan manusia dari kutukan dosa. ${ }^{20}$ Kata kekuatan dan firman saling melengkapi, kata itu memproklamasikan bukan firman dari manusia tetapi firman dari Allah dan firman itu memproklamasikan kekuatan yang membangkitkan yang mati, dan 
menyelamatkan yang hilang. Kata 'kekuatan' dalam pengertian yang lain berkaitan dengan karakter dari Allah sendiri.

Kata 'keselamatan' dalam Roma 1: 16 ditulis dalam bahasa Yunani

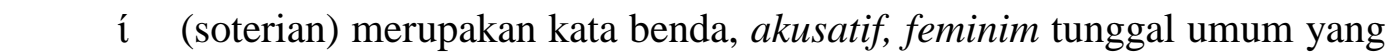

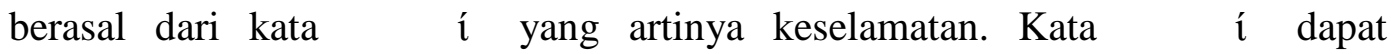
digambarkan seperti orang yang menolong dari bahaya dan memulihkan keadaan seperti semula dan berada dalam keadaan baik. Menolong, menyelamatkan,

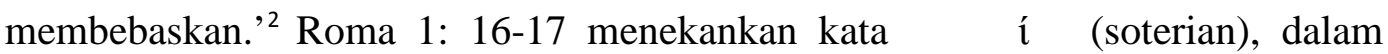
Perjanjian Baru kata tersebut dituliskan sebanyak 8 kali. Kata tersebut diterjemahkan sebagai pekerjaan besar yang telah dikerjakan oleh Kristus untuk menyelamatkan orang yang berdosa. Dalam bahasa Yunani dan Septuaginta (LXX) kata 'keselamatan' diartikan pembebasan dari bahaya dan kematian dan untuk menggambarkan pembebasan yang dikerjakan oleh Allah terhadap bangsa Israel. Perkembangan secara alamiah, kata ini dipakai untuk menggambarkan penyelamatan akhir atas Israel ketika Juruselamat atau Pembebas datang dan penyelamatan ini datang untuk mewakili tentang penyelamatan yang ultimat dari setan, dosa dan kematian. ${ }^{21}$ Sproul menjelaskan kata keselamatan menunjuk pada keselamatan diakhirat atas seluruh dunia. Keselamatan yang dimaksud berisi tentang kebenaran Allah. ${ }^{22}$ Keselamatan ini untuk masa sekarang dan untuk masa yang akan datang.

44.

${ }^{21}$ Matthe Black, The New Century Bible Commentary Bibile (London: Eerdmans Publishing, 1981), 22 R.C. Sproul, Kebenaran-Kebenaran Dasar Iman Kristen (Malang: SAAT, 1997), 229. 


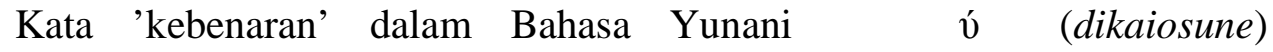
merupakan kata benda, feminism, tunggal, nominative yang memiliki arti kebenaran, kebajikan dan keadilan. Kata ini dalam Perjanjian Baru disebutkan 92 kali dan 36 kali dalam surat Roma. Kata $\delta ı \kappa \alpha \iota \sigma$ (dikaios) (benar/adil) dan

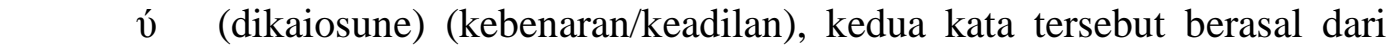
akar kata yang sama dan bercorak hukum. ${ }^{23}$ Kata 'kebenaran' menunjukkan sebuah tindakan yang dilakukan sesuai dengan kebenaran Tuhan, melakukan apa yang Tuhan mau untuk dilakukan, melakukan apa yang benar. Kata ini juga dituliskan dalam Matius 5: 10 yang menujuk kepada orang yang berbahagia karena melakukan kebenaran. Pernyataan Paulus dalam kata 'kebenaran' menggunakan kasus genitive, subjektive yang menunjukkan sebuah pembedaan antara kejahatan manusia dan kebenaran ilahi. ${ }^{24}$ Kebenaran Allah dinyatakan di dalam Injil tentang Anak Allah, berita tentang Allah yang mengutus anak-Nya untuk menyelamatkan manusia yang berdosa.

Kebenaran Allah tidaklah berhubungan dengan kebenaran keadilan-Nya, tetapi kebenaran hanya melalui iman. Pembenaran Allah ini diterima dan

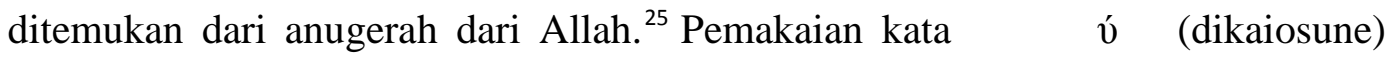
mengajarkan bahwa pusat dari segala kebenaran pada salib Yesus Kristus. Kebenaran yang dimaksud dalam bagian ini adalah kebenaran yang esensial yang berbeda dari pandangan umum. Kebenaran bukan hanya masalah materi atau keberhasilan, namun keselamatan manusia dari hukuman dosa. Kebenaran Allah dinyatakan melalui pengudusan manusia yang berdosa. Pembenaran yang

${ }^{23}$ Donald Guthrie, Teologi Perjanjian Baru, vol. 2 (Jakarta: BPK Gunung Mulia, 1993), 123-124.

24 Hultgren, Paul's Gospel and Mission, 30.

${ }^{25}$ Emil Bruner, The Letter to the Romans (Philadelphia: Wesrminster Press, 1952), 16. 
dinyatakan dalam diri manusia bukan karena perbuatan baik yang dilakukan oleh manusia. kebenaran yang dinyatakan dalam diri manusia terlihat dari tindakan aktif manusia menjadi pasif, karena kebenaran hanya bisa dipahami melalui sikap pasif dan Allah yang bertindak dan mewujudkannya.

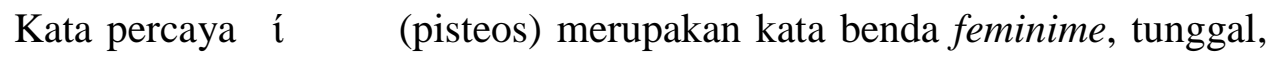
umum, genitive, dari kata dasar jíotı (pistis), kata ini ditulis sebanyak 240 kali dalam Perjanjian Baru, kata ini memiliki arti iman, percaya sesuatu yang dapat dipercaya sepenuhnya dan sesuatu yang layak untuk di percayai. Makna yang ditekankan dalam kata iman dilihat dengan latar belakang karya penyelamatan Allah di dalam dan melalui Yesus Kristus. Inti gagasan Perjanjian Baru adalah Allah mengutus Anak-Nya menjadi Juruselamat dunia. Iman adalah sikap yang melepaskan usaha sendiri untuk mendapat keselamatan hidup yang kekal dan sepenuhnya mengandalkan Yesus Kristus dan berharap keselamatan dari padaNya. Kebenaran diperoleh berdasarkan iman secara aktif. Kebenaran hanya dapat dipahami ketika seseorang beriman atau percaya dengan sungguh-sungguh.

Seseorang yang telah dibenarkan hendaknya tidak lagi takut untuk mewartakan Kabar Baik dengan penuh sukacita, walaupun banyak tantangan yang harus dialami. Kata 'percaya' juga menunjukkan sebuah keyakinan yang tahan uji, tidak hanya percaya tetapi sungguh-sungguh percaya. Kata 'percaya' juga memiliki arti sebagai sebuah karakter yang percaya kepada Allah tanpa ada buktibukti seperti Abraham. ${ }^{26}$ Paulus mengatakan bahwa iman itu adalah sebuah hadiah khusus dari Tuhan diberikan kepada manusia.

${ }^{26}$ William F. Arndt, Greek English Lexicon of the NewTestament (London: Chicago Press, 1957), 669. 


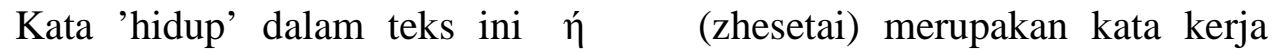

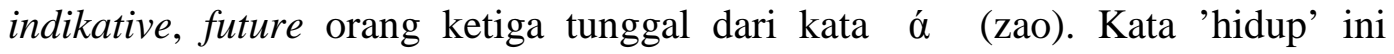
menunjukkan tindakan yang tidak hanya terjadi masa kini, tetapi lebih cenderung berlaku untuk masa yang akan datang. Hidup dalam bagian ini berarti menikmati keselamatan Tuhan secara jasmani dan rohani. Hidup yang dimaksudkan dalam bagian ini tentunya yang pertama dan utama yang dilakukan adalah percaya kepada Tuhan dan mengandalkan Tuhan. Penggunaan istilahi ini secara indikatif future menunjukkan bahwa hidup yang dimaksud dalam bagian ini tidak hanya berlaku untuk saat ini, tetapi bagaimana hidup di masa yang datang yang dinyatakan oleh Yesus Kristus melalui kehidupan yang kekal. Kata $\zeta \omega$ (zo) muncul 140 kali dalam Perjanjian Baru, kata ini digunakan lebih awal dalam kehidupan orang Kristen salah satu sebagai tanda keselamatan. Kehidupan yang dimaksud dalam bagian ini adalah kehidupan yang diberikan oleh Yesus yaitu kehidupan kekal. Siapa pun yang memiliki kehidupan kekal tidak akan kehilangan dan tidak akan masuk dalam penghakiman.

\section{Pengertian Gereja}

Penulis pada bagian ini akan mengimplementasikan hasil eksposisi Roma 1: 16-17 bagi Gereja masa kini. Gereja adalah kumpulan orang-orang percaya kepada Yesus dan yang sudah menerima Yesus sebagai Juruselamat, dengan demikian secara ideal orang yang ada di dalam gereja berarti telah mengalami pertobatan. Gereja adalah lembaga ilahi yang didirikan oleh Yesus Kristus dan dibangun di atas-Nya (Lih. Mat. 16: 18 dan 1Korintus 3: 11). Dalam tulisan David I. Santoso menjelaska gereja bagaikan bangunan di atas dasar para Rasul 
dan Nabi dengan Kristus sebagai Batu Penjuru. ${ }^{27}$ Kata gereja berasal dari kata Portugis yaitu Igreja dari kata Yunani yaitu $\varepsilon \kappa \kappa \lambda \varepsilon \sigma \iota \alpha$ (ekklesia) yang merupakan gabungan dari kata $\varepsilon \kappa \quad(\mathrm{ek})$ artinya 'keluar' dan $\kappa \alpha \lambda \varepsilon i v$ (kalein) artinya 'memanggil', dengan demikian gereja adalah orang-orang yang dipanggil keluar dari sekumpulan orang untuk maksud istimewa (1Petrus 2: 9). ${ }^{28}$ Dick Iverson menuliskan dasar hidup Perjanjian Baru dimulai dengan pertobatan. ${ }^{29}$ Sejatinya di dalam gereja adalah orang-orang yang sudah bertobat atau orangorang yang sudah meninggalkan kehidupan lama (dosa) dan hidup dalam kehidupan yang dikehendaki Kristus.

Matius 16: 18 istilah $\varepsilon \kappa \kappa \lambda \varepsilon \sigma \iota \alpha$ (ekklesia) pertama kali diterapkan bagi orang Kristen oleh Yesus sendiri terhadap Petrus di Kaisarea Filipi. Orang percaya untuk mendirikan sebuah jemaat wajib pergi memberitakan Injil dan memuridkan. Kewajiban tersebut dalam konteks umat Kristen disebut Amanat Agung (Mat. 28: 18-20). Perintah ini merupakan Amanat Agung Tuhan Yesus yang harus dilaksanakan oleh murid-murid-Nya, yaitu setiap orang percaya. Maka sesuai dengan definisi kata gereja menunjukkan bahwa perkumpulan yang dipanggil keluar untuk membawa Injil. Senada dengan hal tersebut G. W. Schweer menjelaskan gereja adalah kumpulan orang percaya yang sudah dibaptiskan dan diikat menjadi satu oleh iman dan persekutuan dalam Kristus, gereja mentaati perintah Kristus, memakai karunia-karunia Allah, gereja memakai

\footnotetext{
${ }^{27}$ Dawson, Memperlengkapi Kaum Awam Satu-B (Yogyakarta: Pelayanan MKK, 1990), 5

${ }^{28}$ Ichwei G. Indra, Teologi Sistematis, Pengetahuan Lanjutan Bagi Kaum Awam dan Anggota Gereja (Bandung: Lembaga Literatur Baptis, 2005), 175

29 Dick Iverson \& Larry Asplund, Gereja Sehat Dan Bertumbuh (Malang: Penerbit Gandum Mas, 2000), 31
} 
kesempatan-kesempatan yang ada untuk memberitakan Injil. ${ }^{30}$ Keberadan gereja adalah untuk mendidik, mendorong, memuliakan, memperlengkapi dan menginjili. Persekutuan orang-orang yang telah ditebus oleh Kristus dan menjadi satu di dalam keluarga Allah. ${ }^{31}$ Gereja Perjanjian Baru adalah sebuah jemaat, sebuah persekutuan orang-orang yang telah ditebus, sebuah komunitas rohani. Gereja yang sehat akan menjangkau jiwa bagi Kristus dan gereja yang sehat tidak takut melakukan penginjilan. ${ }^{32}$ Ketakutan dalam menginjili dapat disebabkan karena masih terlalu kuat rasa kebergantungan dan mengadalkan kekuatan sendiri serta mengabaikan penyertaan Tuhan (Lih. Mat. 28: 20).

Para Teolog yang berfokus pada pertumbuhan gereja memberikan beberapa definisi tentang pertumbuhan gereja. Peter Wagner menjelaskan pertumbuhan gereja adalah segala sesuatu yang mencakup soal membawa orangorang yang tidak memiliki hubungan pribadi dengan Yesus Kristus dalam persekutuan dengan Dia dan membawa mereka menjadi anggota gereja yang bertanggungjawab. ${ }^{33}$ Peter Wagner dalam definisi di atas menekankan bahwa pertumbuhan gereja tersebut meliputi penjangkauan jiwa, dan pendewasaan jiwa hingga bertumbuh serta menjadi murid Kristus yang sejati.

Orlando E. Costas memberikan definisi pertumbuhan gereja adalah ekspansi menyeluruh dan alami yang dapat dan harus diharapkan dari kehidupan dan misi gereja sebagai umat Allah, tubuh Kristus, dan persekutuan Roh.

${ }^{30}$ G. W. Schweer, Langkah-Langkah Menuju Kedewasaan Rohani (Bandung: Lembaga Literatur Baptis, 2000), 51-52.

31 W.L Howse W. O., Thomason, A Dynamic Church: Spirit and Structure for the Seventies (Tennessee: Convention Press, 2008), 3.

32 Takut dalam kamus bahasa Indonesia adalah "merasa gentar (ngeri) menghadapi sesuatu yang dianggap mendatangkan bencana (Lih.: Tim Pustaka Phoenix, Kamus Besar Bahasa Indonesia (Jakarta: Media Pustaka Phoenix, 2009), 830.)

33 C. Peter Wagner, "Buku Gereja Saudara Dapat Bertumbuh," t.t., diakses 27 Oktober 2020, 99. 
Pertumbuhan gereja ini dikatakan menyeluruh karena: Allah merindukan penambahan orang-orang percaya ke dalam gereja, Allah memanggil semua orang percaya ke dalam pemuridan, Allah mencari lebih banyak vitalitas dalam penyembahan dan pemeliharaan gereja, Allah menghendaki gereja membuat perbedaan dalam komunitasnya dengan melawan paksaan dan bentuk-bentuk kejahatan dengan kebenaran dan kuasa Injil yang dihidupi oleh mereka yang memperoleh keselamatan melalui iman. ${ }^{34}$ Pertumbuhan gereja juga dikatakan alami karena Allah menginginkan, mengharapkan, dan memungkinkan terjadinya pertumbuhan gereja.

Peter Wongso menjelaskan pertumbuhan gereja adalah perkembangan dan perluasan tubuh Kristus baik dalam kuantitas maupun kualitas, dalam bentuk yang nampak maupun isinya yang tak tampak. ${ }^{35}$ Sularso Sopater juga memiliki pendapat yang senada, menurutnya pertumbuhan gereja yaitu pertumbuhan yang muncul dari dua sisi yang disebut pertumbuhan intensif yaitu pertumbuhan kedalam (konsolidatif) dan pertumbuhan ekstensif yaitu pertumbuhan keluar ${ }^{36}$ yakni bertambahnya jumlah anggota, kelompok, luas jangkauan pelayanan, organisasi.

Beragam definisi pertumbuhan gereja di atas dapat disimpulkan bahwa pertumbuhan gereja adalah perkembangan dan perluasan tubuh Kristus baik dalam kualitas yaitu berupa kedewasaan rohani jemaat, maupun kuantitas yaitu membawa orang-orang menjadi anggota gereja yang bertanggungjawab. Gereja bukanlah bangunan ataupun organisasi yang hierarki melainkan perkumpulan orang-orang yang telah dipanggil keluar oleh Allah ke dalam suatu jenis

34 Duncan Mclntosh dan Richard E. Rusbuldt, Planning Growth in Your Church (Valley Forge: Judson Press, 1983).

35 Peter Wongso, "Tugas Gereja dan Misi Masa Kini," t.t., diakses 27 Oktober 2020.

${ }^{36}$ Sularso Sopater, "Makalah Seminar Pertumbuhan Gereja," vol. 1998 (Jakarta: Panitia SPG, t.t.). 
komunitas baru, dengan Kristus adalah kepalanya. Gereja meskipun memiliki para pemimpin, namun kehidupan dan kepemimpinan sejati tetap dari atas, yaitu Yesus Kristus. Dari penjelasan-penjelasan tersebut, maka gereja diartikan sebagai suatu persekutuan orang-orang yang percaya kepada Yesus Kristus. Dengan kata lain orang yang percaya kepada Kristus adalah gereja itu sendiri atau gereja secara rohani (Bait Allah) yang mempunyai tugas membawa orang lain menjadi murid Kristus.

\section{KESIMPULAN}

Pembahasan tentang makna Injil berdasarkan Roma 1: 16-17 dan Implementasinya bagi Gereja masa kini, dapat disimpulkan bahwa Injil merupakan kekuatan Allah yang menyelamatkan. Injil adalah kabar baik yang berisi tentang pengampunan dosa dan kehidupan kekal kepada setiap orang yang percaya. Injil menyatakan kebenaran Allah dan memimpin kepada keselamatan. Kekuatan yang di maksud adalah memperbaharui spiritual dan memperbaiki moral seseorang dengan totalitas. Keselamatan hanya dapat diperoleh berdasarkan iman atau percaya secara aktif. Kebenaran hanya dapat dipahami ketika seseorang beriman atau percaya dengan sungguh-sungguh. Setelah beriman kepada Tuhan Yesus sebagai Tuhan tidak cukup tetapi ada tugas yang harus dilakukan dan bukan pilihan yaitu memberitakan Injil. Perintah ini merupakan Amanat Agung Tuhan Yesus yang harus dilaksanakan oleh gereja atau setiap orang percaya. Gereja bukanlah bangunan ataupun hierarki melainkan perkumpulan orang-orang yang dipanggil keluar oleh Allah dari dalam kegelapan (dosa) kepada terang (keselamatan). Dengan kata lain orang yang percaya kepada Kristus adalah gereja itu sendiri atau gereja secara rohani (Bait Allah) yang mempunyai tugas 
membawa orang lain menjadi murid Kristus. Penginjilan adalah suatu rancangan dan karya Allah yang menciptakan bagi diri-Nya suatu umat untuk bersekutu, menyembah serta melayani Dia secara utuh serasi. Penginjilan merupakan tanggungjawab Gereja (orang percaya) untuk memberitakan berita keselamatan dalam kuasa Roh Kudus kepada orang-orang berdosa supaya bertobat dan beriman kepada Yesus serta menjadi murid yang menaati Amanat Agung Tuhan Yesus. Karena tidak ada keselamatan di luar Yesus Kristus (Kis. 4: 12). Dalam Injil Lukas 24: 47 menyatakan dalam nama Yesus Kristus berita tentang pertobatan dan pengampunan dosa harus disampaikan kepada segala bangsa, mulai dari Yerusalem. Paulus menegaskan dalam pemberitaan Injil adalah sebuah keutamaan (Lih. IKor. 9: 16). Dengan demikian dapat disimpulkan bahwa tugas pemberitaan Injil pada zaman Para Rasul dan bagi gereja masa kini merupakan sebuah perintah dari Tuhan Yesus bukan pilihan. Memberitakan Injil adalah suatu gaya hidup bagi Gereja (orang percaya), dapat dilakukan kapan saja, dimana saja dan kepada siapa saja.

\section{KEPUSTAKAAN}

Allen, Clifton J. The Gospel According To Paul. Nashville: Broadman Press, 1956.

Arndt, William F. Greek English Lexicon of the NewTestament. London: Chicago Press, 1957.

Black, Matthe. The New Century Bible Commentary Bibile. London: Eerdmans Publishing, 1981.

Bruner, Emil. The Letter to the Romans. Philadelphia: Wesrminster Press, 1952.

Calvin, John. Commentaries Epistle Of Paul The Apostle The Romans. Michigan: Eerdmans Publishing, 1947.

Cottrell, Jack. Romans Volume 1. Joplin: College Press, 1998.

Douglass, J.D, ed. Ensiklopedia Alkitab Masa Kini. Vol. 1. Jakarta: YKBK, 1992. 
End, Van den. Tafsiran Surat Roma. Jakarta: BPK Gunung Mulia, 1995.

Guthrie, Donald. Teologi Perjanjian Baru. Vol. 2. Jakarta: BPK Gunung Mulia, 1993.

Hakh, Samuel Benyamin. Perjanjian Baru: Sejarah, Pengantar dan Pokok-pokok Teologisnya. Bandung: Bina Media Informasi, 2010.

Hasugian, Saur. "Karaktersik Garam Dunia.” Jurnal Pascasarjana STBI 8, no. 1 (2011): 104-5.

Hultgren, Arland J. Paul's Gospel and Mission. Philadelphia: Fortress Press, 1973.

JR, Harold L. Fickett. Kepercayaan Kaum Baptis, Suatu Pedoman. Semarang: Lembaga Literatur Baptis, 1985.

Laia, Kejar Hidup. "Memahami Tugas Utama Hamba Tuhan Berdasarkan Surat II Timotius 4:1-5 Dan Aplikasinya Pada Masa Kini." Jurnal Teologi Berita Hidup 2, no. 2 (31 Maret 2020): 110-27. https://doi.org/10.38189/jtbh.v2i2.35.

—_. "Prinsip Kedatangan Yesus Ke Dua Kali.” Nias Barat: STTAM, 2019.

- "Sikap Hamba Tuhan terhadap Jemaat yang Mudur dari Pelayanan." Illuminate: Jurnal Teologi dan Pendidikan Kristiani 3, no. 1 (2020): 4060.

McIntosh, Duncan, dan Richard E. Rusbuldt. Planning Growth in Your Church. Valley Forge: Judson Press, 1983.

O., W.L Howse W. Thomason, A Dynamic Church: Spirit and Structure for the Seventies. Tennessee: Convention Press, 2008.

Schweer, G. W. Langkah-Langkah Menuju Kedewasaan Rohani. Bandung: Lembaga Literatur Baptis, 2000.

Sopater, Sularso. "Makalah Seminar Pertumbuhan Gereja," Vol. 1998. Jakarta: Panitia SPG, t.t.

Sproul, R.C. Kebenaran-Kebenaran Dasar Iman Kristen. Malang: SAAT, 1997.

Stuttart, Verlag Kohlhammer G. Exegetical Dictionary Of the New Testament. Michigan: Eerdmans Publishing Company Grand Rapids, 1991.

Subagyo, Andreas B. Pengantar Riset Kuantitatif dan Kualitatif. Bandung: Yayasan Kalam Hidup, 2014. 69.

Tim Pustaka Phoenix. Kamus Besar Bahasa Indonesia. Jakarta: Media Pustaka Phoenix, 2009. 
Tjandra, Lukas. Latar Belakang Perjanjian Baru II. Malang: Gandum Mas, 1994.

Wagner, C. Peter. "Buku Gereja Saudara Dapat Bertumbuh," t.t. Diakses 27 Oktober 2020.

Wallace, Daniel B. Greek Grammar Beyond the Basics. Michigan: Zondervan Publishing House, 1996.

Wilson, Geoffrey B. Romans. Edinburgh: Great Britain, 1977.

Wongso, Peter. “Tugas Gereja dan Misi Masa Kini,” t.t. Diakses 27 Oktober 2020.

Wuest, Kenneth S. Wuest's Word Studies from the Greek New Testament. Michigan: Eerdmans Publishing, 1974. 